\title{
Variability in Cenozoic sedimentation along the continental rise of the Bellingshausen Sea, West Antarctica
}

\author{
Carsten Scheuer $^{\mathrm{a}, *}$, Karsten Gohl ${ }^{\mathrm{a}}$, Robert D. Larter ${ }^{\mathrm{b}}$, Michele Rebesco ${ }^{\mathrm{c}}$, \\ Gleb Udintsev ${ }^{\mathrm{d}}$ \\ a Alfred Wegener Institute for Polar and Marine Research (AWI), Postfach 120161, D-27515, Bremerhaven, Germany \\ b British Antarctic Survey (BAS), High Cross, Madingley Road, Cambridge CB3 OET, UK \\ c Istituto Nazionale di Oceanografia e di Geofisica Sperimentale (OGS), Borgo Grotta Gigante 42/C, 34010 Sconico (TS), Italy \\ ${ }^{\mathrm{d}}$ Vernadsky Institute of Geochemistry and Analytical Chemistry, Russian Academy of Sciences, 19, Kosygin Str, 117975 Moscow, Russia
}

Received 29 September 2004; received in revised form 16 December 2005; accepted 21 December 2005

\begin{abstract}
Seismic reflection profiles, bathymetric and magnetic data collected along and across the continental margin of the Bellingshausen Sea provide new constraints and interpretations of the oceanic basement structure and Cenozoic glacial history of West Antarctica. Evidence for tectonic boundaries that lie perpendicular to the margin has been identified on the basis of one previously unpublished along-slope multichannel seismic reflection profile. By combining several magnetic data sets, we determined basement ages and verified the positions of possible fracture zones, enabling us to improve previous tectonic and stratigraphic models. We establish three main sediment units on the basis of one seismic along-slope profile and by correlation to the continental shelf via one cross-slope profile. We interpret a lowermost unit, Be3 (older then 9.6 Ma), as representing a long period of slow accumulation of mainly turbiditic sediments. Unit Be2 (from about 9.6 to $5.3 \mathrm{Ma}$ ) may represent a period of shortlived ice advances on the continental shelf. The uppermost unit, Be1 (from about 5.3 Ma to present), apparently consists of rapidly deposited terrigenous sediment that we interpret as having been transported to the shelf edge by frequent advances of grounded ice. Listric faults are observed in Be1 and indicate sediment instability due to interactions between different depositional processes. Correlation of the sediment classification scheme with the continental rise of the western Antarctic Peninsula shows obvious differences in sediment depositional patterns. We estimate a very high sedimentation rate for Unit Be1 (up to $295 \mathrm{~m} / \mathrm{my}$ ) which points to an increase in glacial sediment supply due to major glacial outlets that flowed to nearby parts of the shelf edge in Pliocene and Quaternary times. This is in contrast to the situation at the adjacent Antarctic Peninsular margin and many other parts of the continental rise around Antarctica.
\end{abstract}

(C) 2006 Elsevier B.V. All rights reserved.

Keywords: West Antarctica; Bellingshausen Sea; continental margin; continental rise; sedimentation; Miocene; seismic reflection; sediment drifts

* Corresponding author. Tel.: +49 4714831 1948; fax: +49 471 48311271.

E-mail addresses: cscheuer@awi-bremerhaven.de (C. Scheuer), rdla@bas.ac.uk (R.D. Larter), rebesco@ogs.trieste.it (M. Rebesco).

\section{Introduction}

Since ice sheets first advanced onto the continental shelves around West Antarctica, alternations of glacial and interglacial periods have had a major influence on the sediment supply across the shelf and into the deep 
sea. The patterns of deposition of late Cenozoic sediments along the slope and rise of the West Antarctic continental margin reflect interaction between the effects of ice sheet fluctuations, mass transport processes and bottom currents (Larter and Cunningham, 1993; Rebesco et al., 1996, 1997, 2002; Nitsche et al., 2000). Thus, both the sediment stratigraphy and the physiography of the sea floor reflect the history of the West Antarctic glaciation as well as the processes that eroded, transported and deposited sediments on the outer shelf, slope and rise of the continental margin.

The first multi-channel seismic profiles in the Bellingshausen Sea were collected in 1993 (Cunningham et al., 1994). In this paper we present a new profile, AWI-20010001, which connects a grid of previously recorded profiles west of the Antarctic Peninsula with a set of profiles in the western Bellingshausen Sea and eastern Amundsen Sea (Fig. 1). Together with slopeparallel seismic lines in the east and west, it forms a transect that is over $2000 \mathrm{~km}$ long and enables a correlation of deposition and transport processes along the entire West Antarctic continental rise of the south-eastern Pacific.

Previous investigations at different sites on the Antarctic continental margins show glacial related sediment supply to the continental rise since the Late Miocene and a decrease in sedimentation rates since the Pliocene (results from ODP Legs 178 and 188, see e.g. De Santis et al., 1995; Barker and Camerlenghi, 2002; Iwai et al., 2002). The continuation of this survey effort into the largely unexplored Bellingshausen Sea is one of the goals of this study. In particular, this paper will discuss the influence of grounding ice development on sedimentation processes since the Late Miocene.

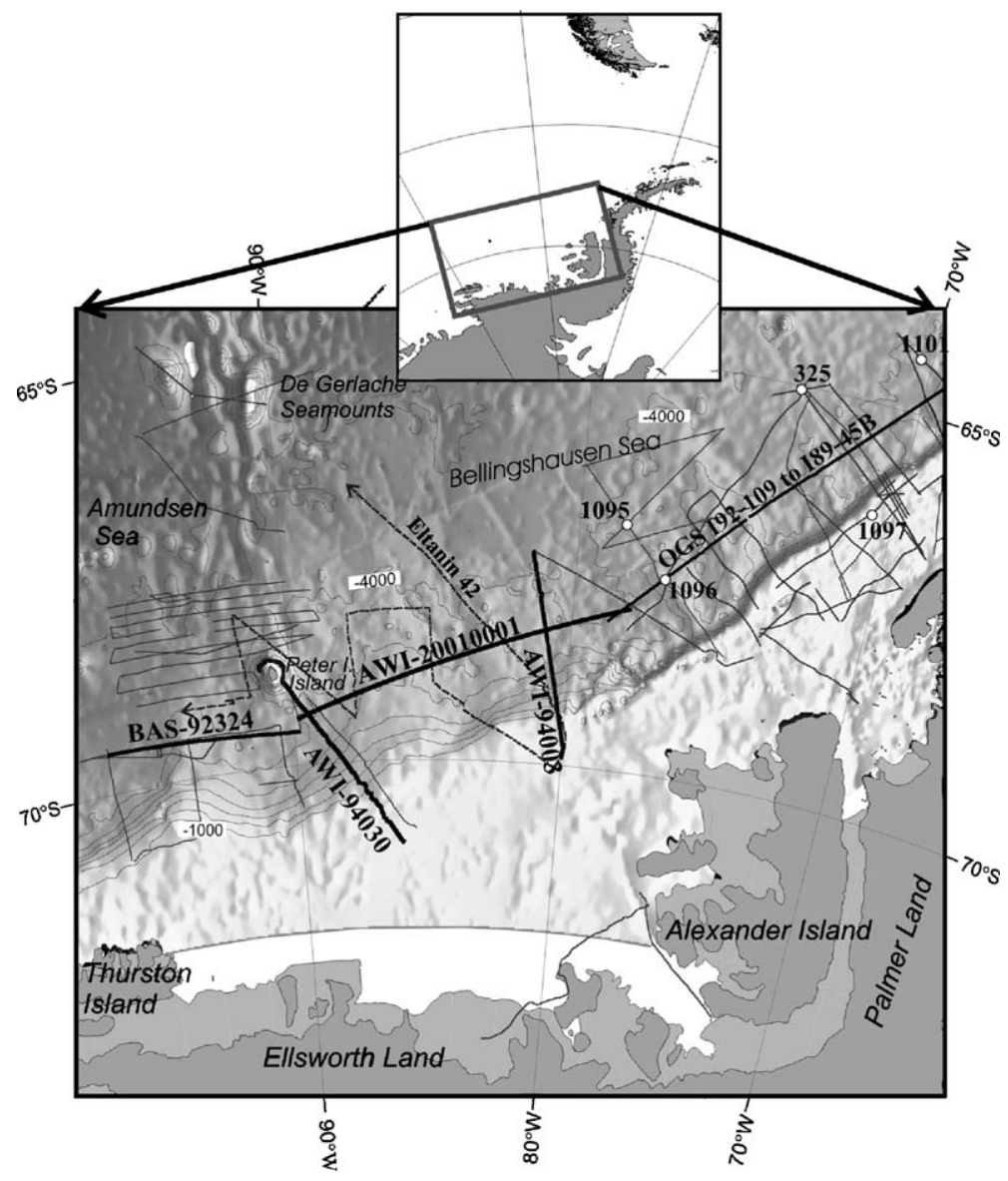

Fig. 1. Satellite-derived predicted bathymetric map (Smith and Sandwell, 1997) of the Bellingshausen and eastern Amundsen Sea and the West Antarctic continental margin with tracks of seismic lines. The multichannel seismic (MCS) profiles AWI-94003, AWI-94030 and AWI-20010001 were recorded in 1994 and 2001, respectively, with RV Polarstern. The British Antarctic Survey collected MCS profile BAS-92324 during a RRS James Clark Ross cruise in 1993. The dashed line shows the track of single channel seismic data, acquired during a USNS Eltanin cruise in 1970 (e.g. Tucholke and Houtz, 1976). The thin lines show additional seismic profiles which are not used in this paper. Drill sites of DSDP Leg 35 and ODP Leg 178 are marked with white dots. 


\section{Tectonic-sedimentary background}

This section briefly summarises previous knowledge of the tectonic and sedimentary history of the West Antarctic continental margin. An understanding of the evolution of the oceanic basement and its tectonic structures is important for the estimation of sediment ages. Furthermore, an understanding of the glacial sediment transport processes should help clarify the relationship between advances of grounded ice on the continental shelf during glacial times and the associated development and structure of sediment deposits on the continental slope and rise.

\subsection{Basement evolution}

The active continental margin of the Bellingshausen Sea and the western Antarctic Peninsula was converted to a passive margin via a series of ridge-trench collisions of the Antarctic-Phoenix ridge that progressively migrated towards the northeast. Such ridge-trench interactions began at about $50 \mathrm{Ma}$ east of Peter I Island and continued until about $3 \mathrm{Ma}$ at the northern end of the Antarctic Peninsula at about $62.5^{\circ} \mathrm{S}$ (e.g. Barker, 1982; Larter and Barker, 1991; Larter et al., 1997, 1999; Eagles et al., 2004b). The spreading corridors that formed by the action of these ridge segments are separated from one another by fracture zones that are oriented approximately perpendicular to the trench.

The boundary with the Amundsen Sea just to the west can be defined along a set of north-south trending tectonic lineations of which the western branch is named the Bellingshausen Gravity Anomaly (BGA). The BGA corresponds to a buried basement trough where Cretaceous oceanic basement dips beneath more elevated basement to the east (Gohl et al., 1997; Cunningham et al., 2002). Convergent motion at this tectonic boundary occurred in the late Cretaceous from 79 to $61 \mathrm{Ma}$ (Larter et al., 2002; Cunningham et al., 2002; Eagles et al., 2004a,b). The oceanic crust in between the BGA and Peter I Island has recently been interpreted as having formed as part of the erstwhile Charcot Plate (Larter et al., 2002; Eagles et al., 2004b).

\subsection{Glacial history and sediment transport}

Geophysical and geological data constraining the glacial history of the Antarctic Peninsula and the Bellingshausen Sea come from both on- and offshore, predominantly from the Antarctic Peninsula margin. The earliest evidence of ice-rafted debris in the region has been found in sediments exposed on the King
George Island in the South Shetland Islands. These sediments were dated as early Eocene by Birkenmajer (1991), but have been reinterpreted as Oligocene sediments by Dingle and Lavelle (1998) and Troedson and Smellie (2002). The earliest ice-rafted debris at DSDP Site 325 was identified in a Middle Miocene core (Hollister et al., 1976). A number of authors interpret compilations of benthic foraminiferal oxygen isotope data (e.g. Miller et al., 1987; Zachos et al., 2001) in terms of major ice-sheet expansions at the EoceneOligocene boundary and in the Middle Miocene. The Eocene-Oligocene shift in oxygen isotope ratios is now widely thought to be related to development of the East Antarctic ice sheet. However, the timing of the first development of large ice sheets on West Antarctic continental shelves remains a subject of debate. Data from the Pacific margin between the Antarctic Peninsula and the Ross Sea are sparse, but geophysical and ODP data acquired from the continental shelf and rise (Location shown in Fig. 1) give evidence that glacially transported sediments were supplied to the continental margin in the middle to Late Miocene (e.g. Bart and Anderson, 1995; Rebesco et al., 1997; Larter et al., 1997; Nitsche et al., 1997; Barker and Camerlenghi, 2002). A major change in sequence geometry on the outer shelf (start of progradation) was dated as Late Miocene at ODP Site 1097 and interpreted as the start of regular advances of grounded ice to the shelf edge (Barker and Camerlenghi, 2002). A widely held conceptual model of glacial sediment transport processes on this margin may be summarized as follows:

Deformation of subglacial till beneath ice streams is thought to be the main mechanism transporting sediment to the shelf edge, at least during the Late Miocene, Pliocene and Quaternary (Larter and Cunningham, 1993; Dowdeswell et al., 2004a). The ice grounding line advanced and retreated, controlled by climatic forcing and ice-sheet dynamics. During glacial maxima, grounded ice extended to the continental shelf edge, resulting in the transport of sediment by ice streams and deposition onto the slope (Fig. 2). Thus, prograding sequences and large oblique wedges developed often on the outer shelf and slope (e.g. Larter et al., 1997). Mass transport processes (slumps, slides, debris flows and turbidity currents) transported large volumes of sediment material from the continental slope to the deep basin. Numerous, large turbidity current channels, which cut on the lower slope and rise, are identified on many parts of the continental margin (e.g. Tomlinson et al., 1992; McGinnes et al., 1997; Anderson et al., 2001, Rebesco et al., 2002; Dowdeswell et al., 2004b). 


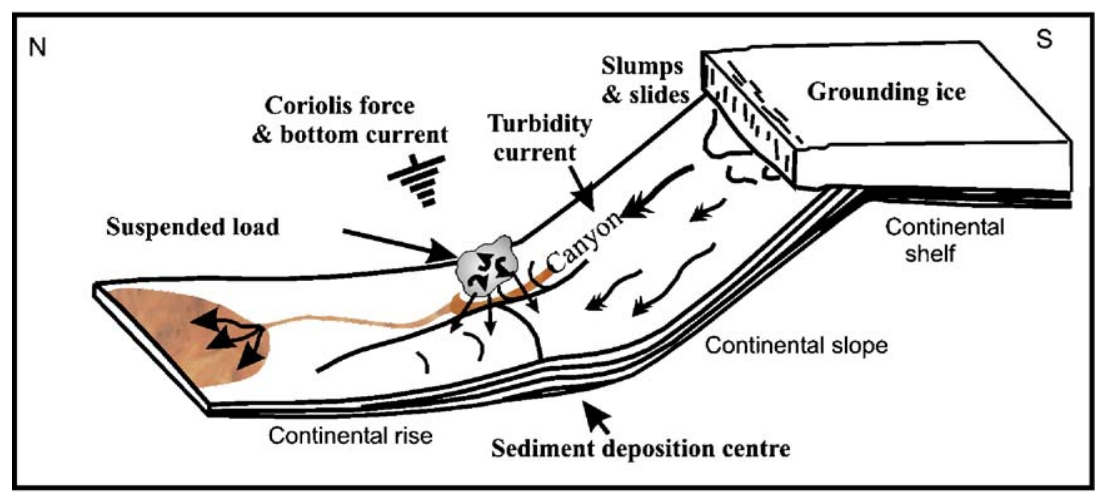

Fig. 2. Transport processes of eroded sediment material across the slope and depositional processes on the continental rise along the West Antarctic margin during glacial maxima (modified after Rebesco et al., 1997).

\subsection{Physiographic expression}

Published data on the physiographic expression of the Bellingshausen Sea is very sparse, coming from satellite derived bathymetry data (Smith and Sandwell, 1997) and a few seismic profiles (Fig. 1). The satellite bathymetry suggests a relatively even continental shelf and shelf widths varying from about $390 \mathrm{~km}$ east of Thurston Island to about $480 \mathrm{~km}$ west of Alexander Island. Three lobes on the continental shelf break that may have been produced by oceanward migration can be observed. Sediment supply from the vicinity of these lobes seems to have fed large sediment depocentres on the continental rise. The continental slope in the Bellingshausen Sea is gently inclined with a gradient between $1^{\circ}$ and $4^{\circ}$ and thus shallower than the slope observed northeast of $77^{\circ} \mathrm{W}$ along the western Antarctic Peninsula (gradient between $13^{\circ}$ and $17^{\circ}$ ) (e.g. Cunningham et al., 1994; Nitsche et al., 1997).

\section{Magnetic database}

We interpreted helicopter magnetic data that were acquired during the $R V$ Polarstern cruise ANT18-5a in 2001 in the eastern Bellingshausen Sea in order to investigate basement tectonic structures. Acquisition was with a Scintrex ${ }^{\mathrm{TM}}$ caesium-vapour magnetometer. The sensor tow-length was $30 \mathrm{~m}$. Altitude ranged between 150 and $300 \mathrm{~m}$, and the average helicopter speed was about $80 \mathrm{kn}$. Values of total magnetic intensity (measured in $\mathrm{nT}$ ) were sampled at $100-\mathrm{ms}$ intervals. All total magnetic intensity data were subsequently processed to eliminate high-frequency noise and spikes, and the global magnetic reference field (IGRF) was then subtracted from the data.

\section{Seismic database and observations}

Two cross-slope MCS profiles, AWI-94003 and AWI-94030, permit correlations between the outer continental shelf and the along-slope MCS profiles AWI20010001 and BAS-92324 on the continental rise and, thus, enable a determination and interpretation of the sedimentary architecture on the continental margin of the Bellingshausen Sea. The recording methods for, and processing of the two cross-slope profiles are described by Nitsche et al. (1997). The acquisition and processing of Profile BAS-92324 were described by Cunningham et al. (1994). Profile AWI-20010001 was recorded using a 96 channel, $600 \mathrm{~m}$ hydrophone streamer and an array consisting of eight airguns with a total chamber capacity of 241 . The shot interval was $12 \mathrm{~s}$ and the sampling interval was $2 \mathrm{~ms}$. The seismic data were processed with standard procedures. After demultiplexing and applying a spherical divergence correction, the data were sorted and binned into $12.5 \mathrm{~m}$ spaced CDP's. A bandpass filter between 10 and $90 \mathrm{~Hz}$ was applied prior to normal move-out correction and stacking. We used a deconvolution filter to minimize the bubble effect and sharpen the reflection arrivals. Due to the short streamer and thus short move-out, the quality of the velocity model was not good enough for an appropriate estimate of interval velocities. Hence, all depth values in the following section are only roughly estimated by assuming an average interval velocity in sediment of $2000 \mathrm{~m} / \mathrm{s}$.

\subsection{Basement structure}

The along-slope seismic reflection profile AWI20010001 (Figs. 3, and 4a, b and c) shows a distinct sediment-basement boundary, characterised by a downwards change from weak to very strong reflectivity. The 


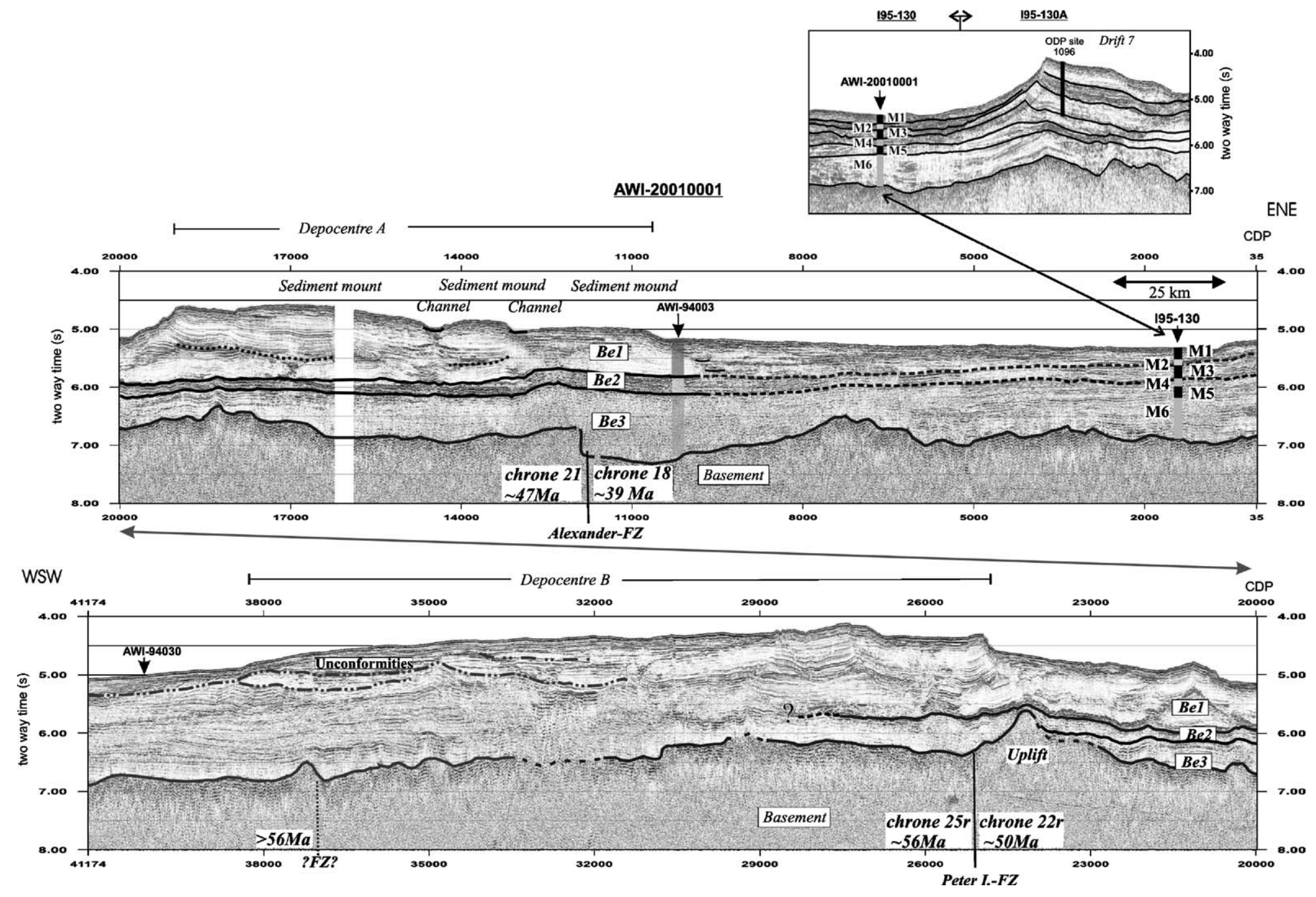

Fig. 3. Seismic reflection profile AWI-20010001, showing the inferred fracture zones and sediment units Be1-Be3. The eastward correlating profile I95-130 (shown above AWI-20010001) clarifies the age-correlation between both sediment classification schemes. 
a wsw

AWI-20010001

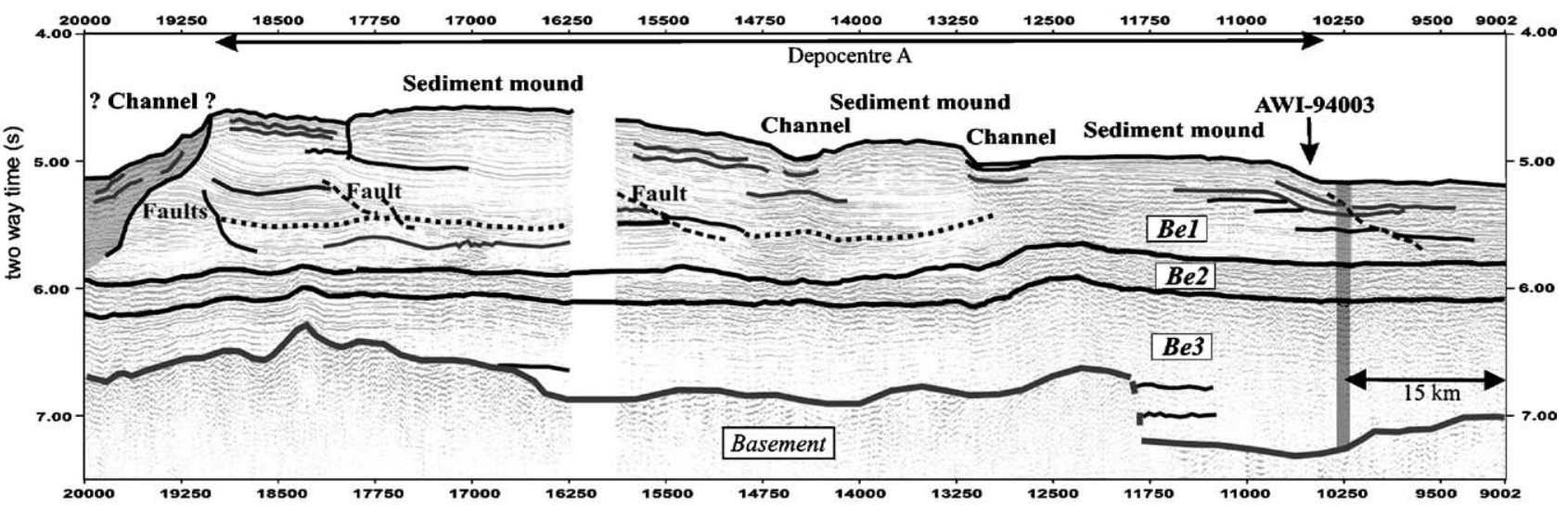

b

AWI-20010001

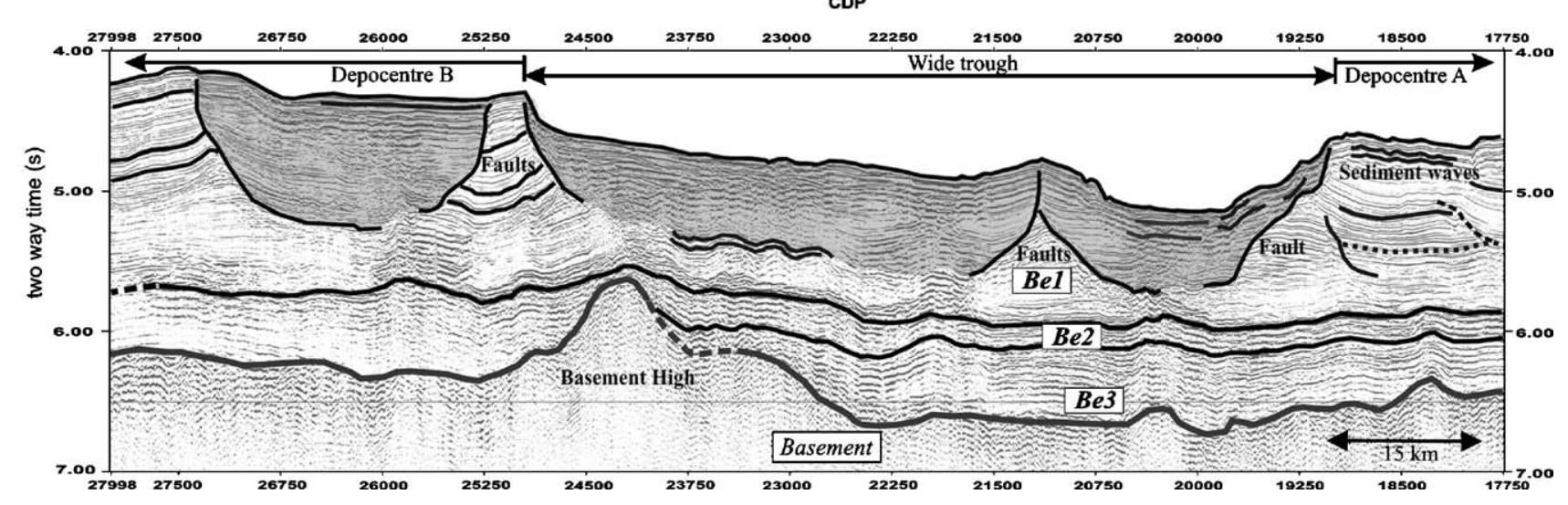

Fig. 4. Profile AWI-20010001 between (a) CDP 9000 and 20000, (b) CDP 17750 and 28000 and (c) CDP 24000 and 40000 with detailed sediment units. Arrows mark intersections with profiles AWI-94003 and AWI-94030 


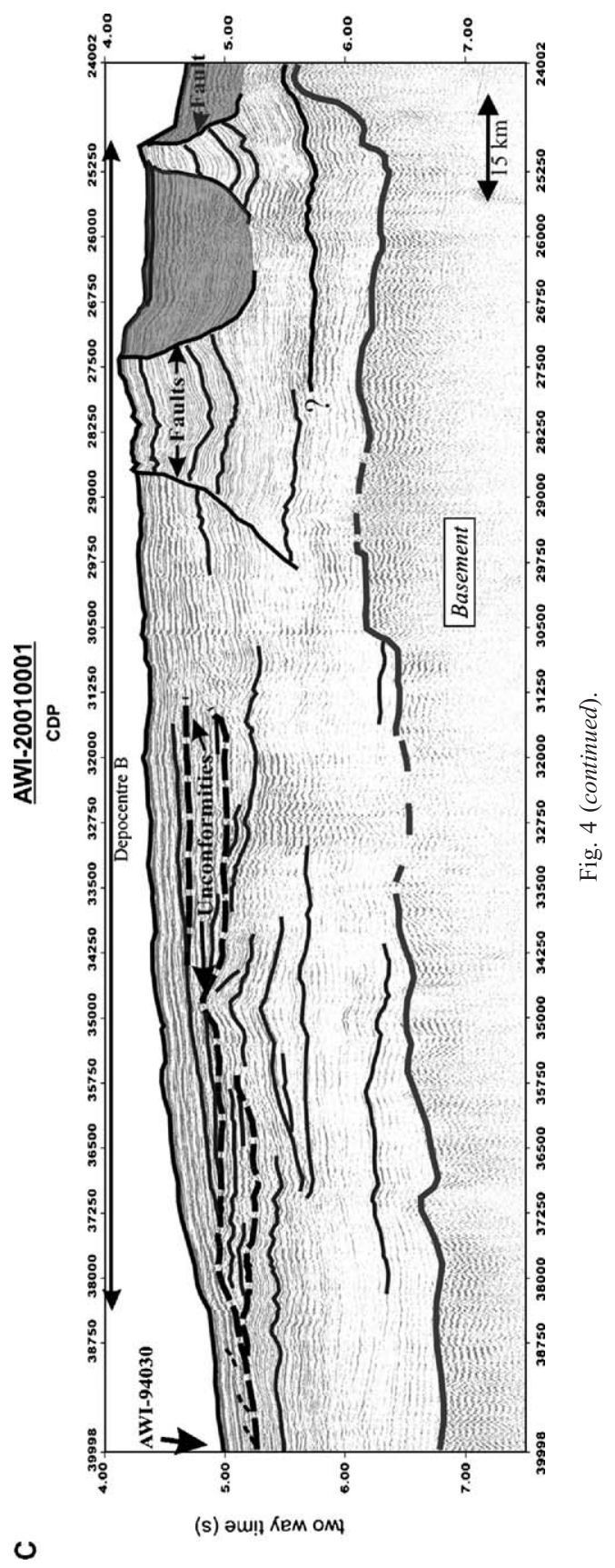


basement surface shows considerable relief, with basement highs, depressions and vertical offsets. Most conspicuous of these are a basement depression between CDPs 8000 and 11750 (up to $7.5 \mathrm{~s}$ TWT, about $2250 \mathrm{~m}$ b.s.f.), a steep basement step, of about $0.5 \mathrm{~s}$ TWT, to the west, and a wide basement high between CDPs 22500 and 25000. This basement high rises to approximately $5.8 \mathrm{~s}$ TWT (about $1000 \mathrm{~m}$ b.s.f.) with a relief of about $0.75 \mathrm{~s}$ TWT on the eastern side. The basement surface west of this basement high descends slightly to $6.75 \mathrm{~s}$ TWT at the end of the profile.

Continuing farther west, on profile BAS 92324 (Fig. 5), the basement surface descends smoothly westward between CDPs 1 and 1900. The rough and elevated basement between CDPs 1900 and 4000 descends to the west at a similar angle but it is characterized by several basement steps. West of CDP 5100, the basement rises up to $6 \mathrm{~s}$ TWT (400 m b.s.f.) towards a wide basement high at CDP 8200 on the eastern side of the BGA. The steep westerly dipping flank of the basement high dips to more than $8.5 \mathrm{~s}$ TWT $(>2700 \mathrm{~m}$ b.s.f.), indicating the tectonic boundary at the BGA.

\subsection{Sediment units}

The cross-slope profiles AWI-94003 and AWI94030 stretch from the outer shelf to the continental rise and cross profile AWI-20010001 near its eastern and western ends (at CDPs 10500 and 40000), respectively (Figs. 1 and 3). Profile AWI-94003 (Fig. 6) shows three units, Unit 1-Unit 3, previously defined beneath the outer shelf by Nitsche et al. (1997), and allows a regional continuation of their boundaries up to profile AWI-20010001 on the continental rise. This profile shows three sedimentary units, named as units Be1-3, whose boundaries present the distal paraconformities of the unit boundaries beneath the outer shelf. Be1-Be3 show different seismic reflections characteristics between CDPs 10000 and 28000 (eastern section, Figs. 3, and $4 a, b$ and $c$ ). The lower unit, $\mathrm{Be} 3$, is characterized by low-amplitude and sub-parallel to parallel reflections, which are overlain by a set of strong reflections, unit $\mathrm{Be} 2$. The upper unit, Be1, is characterized by distinct parallel but weaker and faulted reflections and gentle mounds separated by channels.

In order to estimate sediment ages, we correlated the boundaries of units $\mathrm{Be} 1-\mathrm{Be} 3$ with previously established seismic units on the western Antarctic Peninsula continental rise (Rebesco et al., 1997) and continued the boundaries along assumed isochron reflections of profile AWI-20010001. The classification into three units cannot be adopted on profile AWI-20010001 west of about CDP 28000, where the sedimentary reflectors are characterised by undulations and unconformities (middle section). Accordingly, we describe the western part of the profile separately. Farther west, within the domain of the BGA, the sediments are strongly affected by basement tectonics as seen on profile BAS-92324 (western section, Fig. 5). This profile was previously described by Nitsche et al. (1997) and Cunningham et al. (2002) and here we give only a short overview of the main seismic features that are important for the later discussion.

\subsubsection{Eastern section (profiles AWI-94003, AWI-20010001)}

\subsubsection{Outer continental shelf units (Unit 1, Unit 2,} Unit 3). On the cross-slope profile AWI-94003, the lowermost outer shelf unit, Unit 1, consists of parallel and gently seaward dipping reflections, which are truncated seaward along the Unit 1/Unit 2 boundary (Fig. 6). Unit 1 closely resembles the Type IIA sequence as defined by Cooper et al. (1991) at various locations along the Antarctic continental margin. Unit 2 shows upward increasing seaward inclination of the reflections and truncation of reflections on top of the shelf deposits. On the basis of identification of foreset reflections and defining Unit 2 as containing few oblique foreset truncations beneath the outer shelf, we place the Unit 1/Unit 2 boundary approximately $0.8 \mathrm{~s}$ deeper than Nitsche et al. (1997) did. The uppermost unit, Unit 3, shows a mainly prograding character on the outer shelf, building a sediment wedge on the slope, whereas the uppermost $0.3 \mathrm{~s}$ TWT near the shelf edge is characterised by a smooth decrease in progradation. In contrast to Nitsche et al. (1997), we consider the Unit 2/Unit 3 boundary to lie about $0.2 \mathrm{~s}$ TWT deeper, because we interpret the boundary as the deepest erosional truncation to cross the entire outer shelf and truncate the top of Unit 2 on profile AWI-94003. Unit 3 and Unit 2 are characterized as having a Type IA geometry, after Cooper et al. (1991).

\subsubsection{Lowermost continental rise unit (Be3). The} lowermost sedimentary unit, Be3, that we define on Profile AWI 20010001 is a succession of weak but mostly horizontal and parallel-bedded reflections with variable amplitudes (Figs. 3, 4a and b). The maximum thickness of Be3 is $0.9 \mathrm{~s}$ TWT in the eastern part of the profile (at about CDP 10500). Due to its low reflectivity, no distinct faults, hiatuses, or buried channels can be identified within Be3. The basal sediments fill basement 


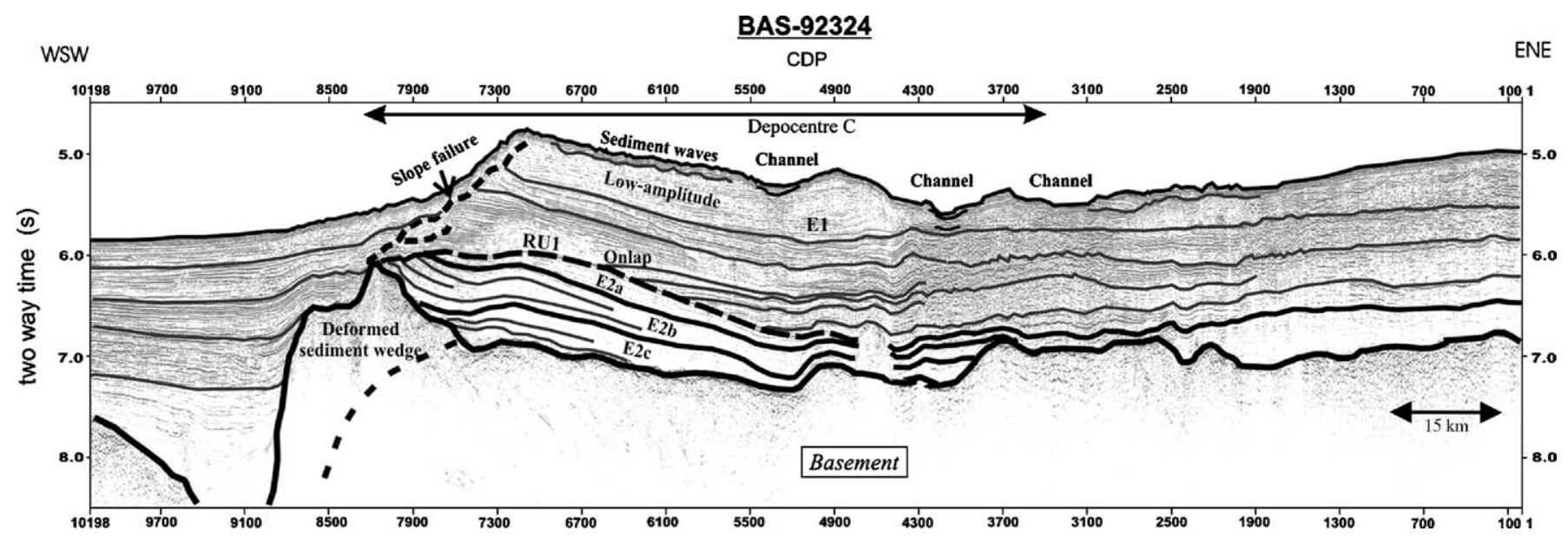

Fig. 5. Profile BAS-92324 between CDP 1 and 10200 with sediment units, modified after Cunningham et al. (2002) and Nitsche et al. (1997). 


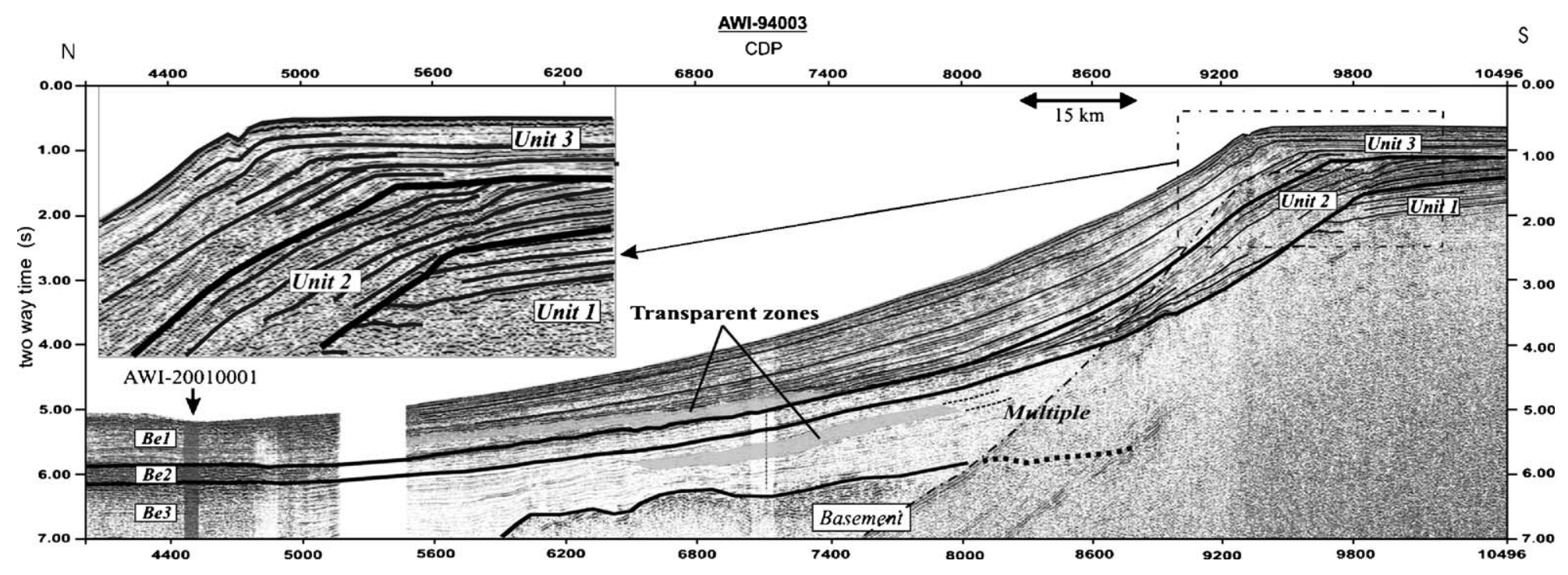

Fig. 6. Profile AWI-94003 with sediment units, Units 1-3, modified after Cunningham et al. (2002) and Nitsche et al. (1997). 


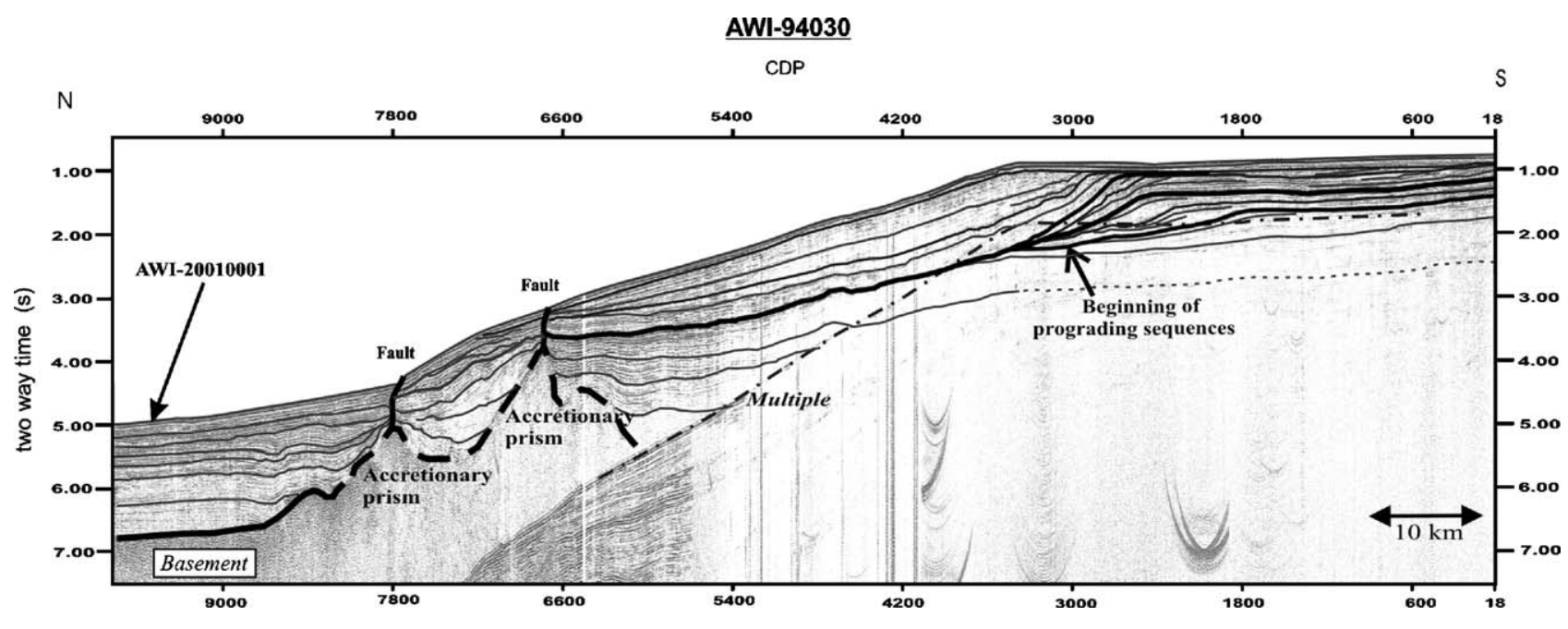

Fig. 7. Profile AWI-94030 with seismic stratigraphic sections, modified after Cunningham et al. (2002) and Nitsche et al. (1997) 
troughs and onlap the basement steps and most other basement highs, indicating pre-sedimentary tectonic activity (e.g. CDP 2500, 11900). The low reflectivity of this unit changes to stronger parallel reflections between CDP 18250 and the basement high at about CDP 24000. The sediments that cover the crest of the basement high are uplifted, which indicate post-sedimentary tectonic activity.

\subsubsection{Intermediate continental rise unit (Be2). The} low-amplitude reflections of unit Be3 are covered by a set of continuous and high amplitude reflections, unit Be2 (Figs. 3, 4a and b). The transition between these two units is gradual. The thickness of $\mathrm{Be} 2$ varies between approximately $0.4 \mathrm{~s}$ TWT (e.g. CDP 14250) and $0.5 \mathrm{~s}$ TWT (CDP 17750). Approaching the eastern side of the basement high (at about CDP 24000), the bound- ary becomes less clear due to the high-amplitude character of reflectors in both $\mathrm{Be} 2$ and $\mathrm{Be} 3$.

\subsubsection{Uppermost continental rise unit (Be1). A} change from the strong reflections of unit $\mathrm{Be} 2$ to the weaker reflections of unit $\mathrm{Be} 1$ above indicates a distinct change in depositional conditions (Figs. 3, 4a and b). Along profile AWI-20010001, Be1 can be seen to occur in two broad sediment depocentres, which we named Depocentre A (CDPs 10000-20000, east-west extent of approx. $125 \mathrm{~km}$ ) and Depocentre B (CDPs 24500 38750 , extent of approx. $180 \mathrm{~km}$ ). Two channels divide Depocentre A into three sediment mounds (Figs. 3 and 4a). The lowermost part of Unit Be1 within Depocentre A shows low-amplitude reflections (Fig. 4a). This character changes upward to long, continuous, parallel, higher-amplitude, and smoothly undulating reflections.

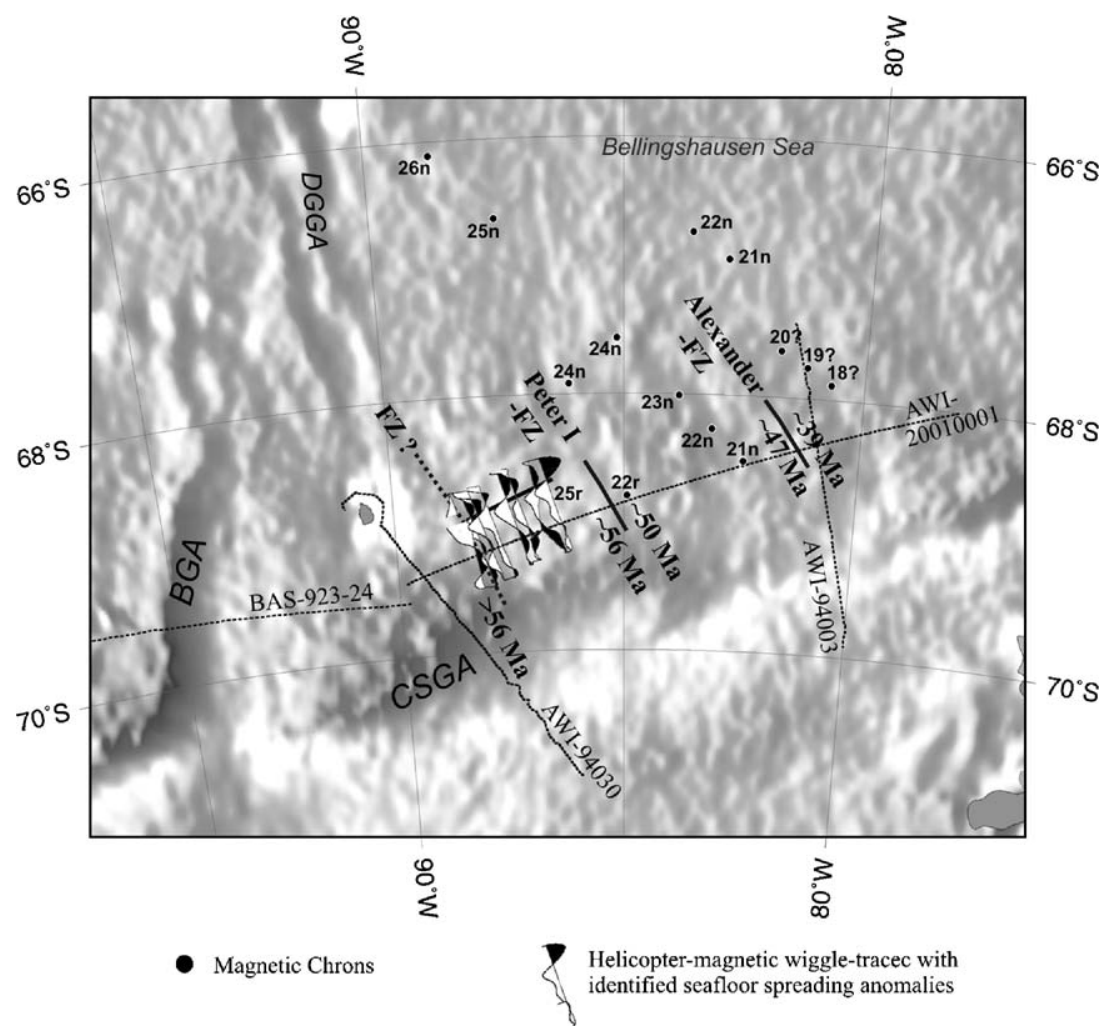

Fig. 8. Illuminated satellite-derived gravity anomaly map (McAdoo and Laxon, 1997) of the Bellingshausen Sea margin with isochrons identified from several cruises' ship-magnetic data and helicopter-magnetic data: The anomaly identifications $22 \mathrm{n}$ and $21 \mathrm{n}$ in the northwest are from a profile collected by $R / V$ Nathaniel B Palmer 9308 (2003), which we obtained from the National Geophysical Data Center GEODAS database (available online at http://www.ngdc.noaa.gov/mgg/gdas/gd_sys.html). The anomaly identifications to the southeast marked with question marks (20n-18n) are from a R/V Hakurei-Maru (1981) profile first published by Kimura (1982). Our interpretation of this profile is different from that published by Kimura. We interpret the anomaly he labelled as 20 as $18 \mathrm{n}$. The two lines of anomaly identifications from $26 \mathrm{n}$ to $21 \mathrm{n}$ and from $24 \mathrm{n}$ and $22 \mathrm{r}$ were acquired by USNS Eltanin 42 in 1970. A synthetic magnetic anomaly profile justifying the interpretation of the anomalies on the first of these two lines is included in McCarron and Larter (1998). The helicopter-magnetic wiggle plots in the eastern Bellingshausen Sea were produced from tracks flown during a $R / V$ Polarstern cruise in 2001. 
The uppermost $0.2 \mathrm{~s}$ TWT of Be1 show high-amplitude reflections and locally irregular sediment waves (e.g. CDPs 17000-19000). The ocean floor is rough, and two recent channels (CDPs 13000 and 14500) can be seen. Patches of chaotic and irregular reflections occur in a wide trough west of sediment Depocentre A (between CDP's 19250 and 24750), dissected by rounded, listric faults (Fig. 4b). Unit Be1 shows a similar succession of reflections in Depocentre B (CDP's 24750 to 28000), but they appear even more irregular, disturbed and wavy (e.g. CDP 28750) (Fig. 4b and c).

\subsubsection{Middle section (profiles AWI-94030, AWI-20010001)}

The characteristics of the sedimentary reflections change within Depocentre B, west of approximately CDP 28000. The lowermost 0.7-1.0 s TWT show weak and smooth reflectivity, so that there is no clear basis for differentiation of units $\mathrm{Be} 3$ and $\mathrm{Be} 2$. The uppermost 1-1.5 s TWT appear more laterally variable in reflection amplitude, showing sediment bulges (CDP 34750) and buried sediment waves (between CDPs 37250 and 38750). Inside this uppermost rough section we can identify unconformities (dashed lines, Fig. 4c), shown by onlapping and downlapping reflectors.

The cross-slope Profile AWI-94030 serves as another seismic connection between the continental rise and shelf (Fig. 7). This profile reveals two acoustic basement highs on the continental slope (CDP 5700 to 8800 ), interpreted as the top of an accretionary wedge, and probably composed of deformed and consolidated sediments (Cunningham et al., 2002). These features are probably the source of the negative "Continental Slope Gravity Anomaly" (CSGA) between $87^{\circ} \mathrm{W}$ and $92^{\circ} \mathrm{W}$ (Fig. 8). We identify several sedimentary sequences on the outer shelf where the prograding character increases upwards, following Nitsche et al. (1997). The boundaries of these sequences seem to merge farther down the slope (bold line), but reflectors cannot be reliably correlated with sediment deposits on the shelf due to the acoustic basement highs and faults within the sediment sequences.

\subsubsection{Western section (profile 92324)}

The sediments in the western section of the Bellingshausen Sea, within the domain of the BGA, are strongly affected by the underlying basement tectonics as seen on profile BAS-92324 (Fig. 5). An obvious sedimentary feature is a prominent unconformity, RU1, on the western side of the basement high (bold dashed line). Cunningham et al. (2002) divided the underlying sediments into three sediment units, E2a, E2b and E2c. Unit E2c consists of mostly basement-parallel reflectors and onlaps the crest of the basement high. All three units thin out to the east whereas Units E2b and E2a are truncated by RU1 to the west. This gently eastward dipping unconformity is characterised by onlap of the overlying reflectors, but it does not continue east of CDP 5000.

\section{Discussion}

\subsection{Tectonic implications}

Studies of magnetic seafloor spreading anomalies on the continental margin of the Bellingshausen Sea define basement ages ranging from 30 Ma northwest of Alexander Island (Larter and Barker, 1991) to $45 \mathrm{Ma}$ in the Bellingshausen Sea at about $87^{\circ} \mathrm{W}$ (McCarron and Larter, 1998) (Fig. 8). The basement step at CDP 11900 on Profile AWI-20010001 seems to coincide with a change in basement age from about $39 \mathrm{Ma}$ (chron 18) in the east to about $47 \mathrm{Ma}$ (chron 21) in the west (Figs. 3 and 8), if chron 18 is accurately extrapolated from observed anomalies further northeast along the paleo-subduction zone. We interpret this basement step as a fracture zone (FZ), here named the Alexander FZ, although a clear identification in the satellite-derived gravity anomaly field is not possible. Another basement offset occurs at CDP 25000, with its eastern side elevated by about $0.5 \mathrm{~s}$ TWT. We suggest that this step may also have formed at a FZ, here named Peter I FZ (in reference to Kimura, 1982), because at the margin it separates anomaly $22 \mathrm{r}$ (50 Ma) in the east from anomaly $25 \mathrm{r}(56 \mathrm{Ma})$ in the west. The Alexander and Peter I FZs were previously interpreted as extensions of the Heezen and Tharp FZs, respectively (Barker, 1982). However, the Heezen and Tharp FZs were formed at the Pacific-Antarctic ridge and its precursor, the Pacific-Bellingshausen ridge, whereas the Alexander and Peter I FZs were formed in the Antarctic-Phoenix spreading system (e.g. Larter et al., 2002). Other basement offsets occur at CDPs 16250 and 37000 , but magnetic data are too sparse to be able to say if they are related to FZs as well.

Basement ages west of the Peter I FZ, within the suggested Charcot plate fragment, remain uncertain due to a lack of reliable magnetic data. However, the lowermost sediments on the eastern part of profile BAS92324 (CDP's 2100 and 4000) onlap uplifted basement segments, indicating tectonic movements prior to sedimentation (Fig. 5). The unconformity RU1 on the eastern side of the BGA, and the lowermost, slightly elevated, sediments above the unconformity indicate post-sedimentary movements on this eastern side of 
the BGA, which represented a zone of convergence between 79 and 61 Ma (e.g. Eagles et al., 2004a,b; Larter et al., 2002; Gohl et al., 1997). If we assume that the unconformity formed at the end of uplift along the BGA at around $61 \mathrm{Ma}$ (e.g. Cunningham et al., 2002), the sediments beneath this unconformity must be older than $61 \mathrm{Ma}$. It is possible that the westward thickening of the minor sedimentary units E2a, E2b and E2c (Cunningham et al., 2002) indicate a slightly westward dipping orientation of the basement before the uplift. The occurrence of three different minor units may indicate several phases of tectonic movements along the BGA (e.g. Eagles et al., 2004b). Alternatively, it cannot be excluded that bottom currents and climate changes might have been responsible for the differing reflection characteristics and deposition rates of these minor units.

\subsection{Sedimentation processes}

\subsubsection{Geometric expression}

Based on satellite-derived predicted bathymetry (Smith and Sandwell, 1997, Fig. 1) and seismic profiles (Figs. 3 and 5) we identified three sediment depocentres on the continental margin of the Bellingshausen Sea, lying in front of three shelf edge lobes. We refer to these as Depocentres A, B and C, from east to west (Fig. 9). Channels dissect Depocentre A into three minor sediment mounds that do not show the typical characteristics of sediment drifts as those observed along the

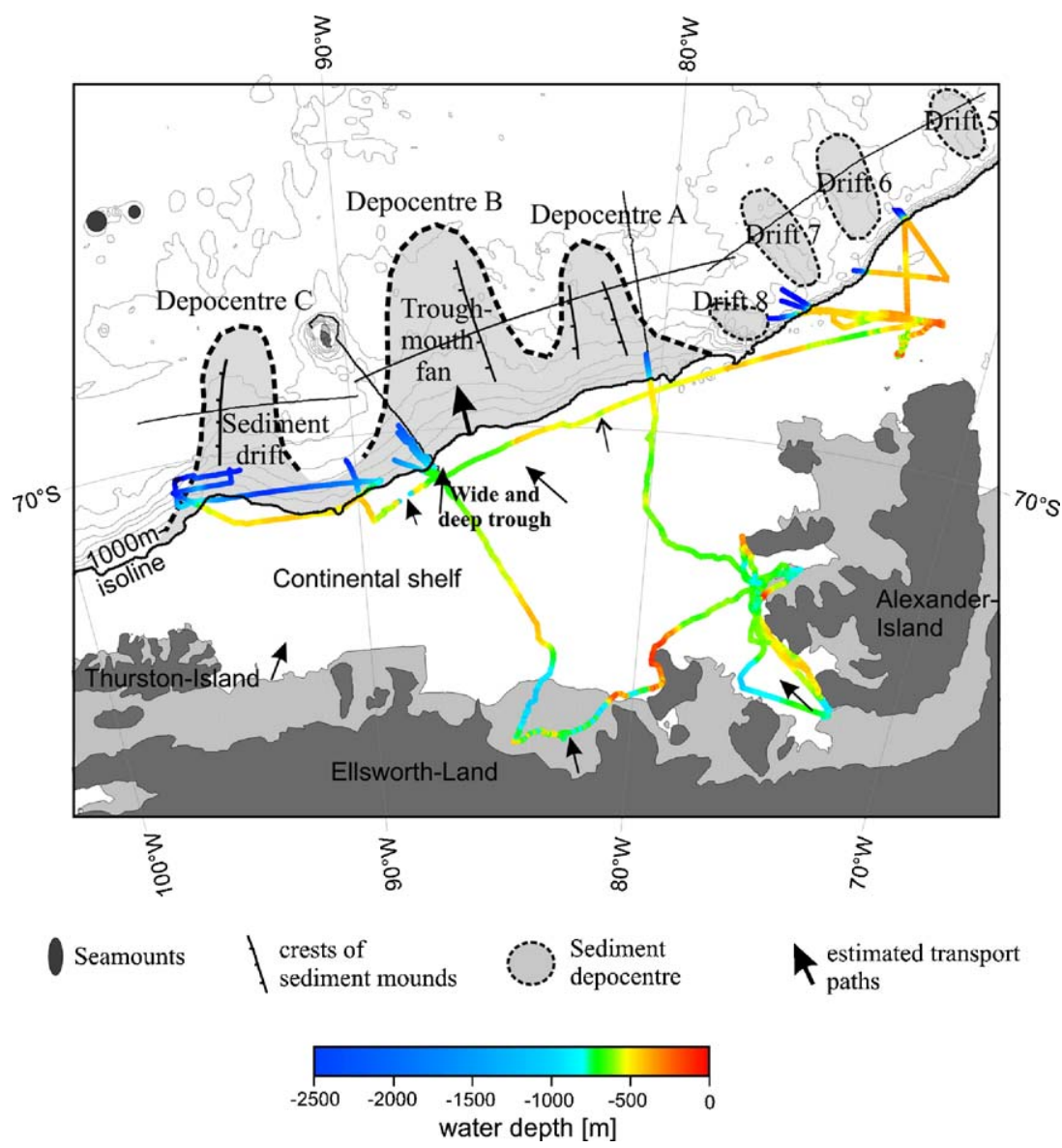

Fig. 9. Schematic model of sediment transport processes along the continental margin of the Bellingshausen Sea. Sparse bathymetric ship track data over the wide continental shelf between Alexander Island and Thurston Island, acquired on RV Polarstern cruises in 1994 and 2001, reveal depressions that may be parts of major cross-shelf glacial transport pathways. They show a broad trough in front of sediment Depocentre B, with water depths of up to $680 \mathrm{~m}$ in the centre and about $450 \mathrm{~m}$ at the rim. The existence of this trough is confirmed by additional bathymetric data recently collected on RRS James Clark Ross (Ó Cofaigh et al., 2005) and is consistent with our interpretation of Depocentre B being a wide deep-sea trough-mouth fan. A further, but shallower, outer shelf depression was observed farther northeast along the shelf-edge in front of sediment Depocentre A and may indicate the presence of a further, smaller glacial trough. The locations of the sediment drifts along the Antarctic Peninsula are schematically adopted from Rebesco et al. (2002). 
western Antarctic Peninsula. Depocentre B is the broadest and lies in front of a seafloor depression on the continental shelf indicated by bathymetric ship track data (Fig. 9) and verified by multibeam echo soundings surveys on the outer shelf (Ó Cofaigh et al., 2005; Larter et al., 2004). Depocentre C lies over uplifted basement along the BGA lineation and constitutes a large asymmetric sediment mound with an east-west extent of about $100 \mathrm{~km}$. This mound has been interpreted as a sediment drift, characterized by a steep western and a gentle eastern side, and two recent channels are observed on its gentle side (e.g. Nitsche et al., 1997). This entire depositional geometry on the continental rise of the Bellingshausen Sea is different to that on the adjacent Antarctic Peninsula margin where continental rise deposits developed as several discrete sediment mounds and drifts that are clearly separated by erosional channels (e.g. Rebesco et al., 1997, 2002).

\subsubsection{Nature of sedimentary units}

The correlation between continental rise- and shelf deposits via profile AWI-94003 and different seismic reflection characteristics of units $\mathrm{Be} 1, \mathrm{Be} 2$ and $\mathrm{Be} 3$ shows different sediment accumulation patterns, suggesting changes of sediment supply processes. We assume a mainly turbiditic origin for the lowermost continental rise unit $\mathrm{Be} 3$, following the interpretation, of "Pre-drift" and "Drift-growth" stages along the western Antarctic Peninsula by Rebesco et al. (1997). On the continental rise, the sediments infill low lying areas first and onlap onto basement topography, which is typical for turbidites. Furthermore, Early Miocene sediments, recovered in the deepest cores at DSDP Site 235, are primarily mostly terrigenous (Hollister et al., 1976).

The seismic characteristics of the outer shelf units, Unit 2 and Unit 3 (Fig. 6), appear similar to the sediment sequence groups S3-S2 and S1, respectively, which were established on the continental shelf of the western Antarctic Peninsula (e.g. Larter and Cunningham, 1993; Larter et al., 1997; Barker et al., 1999). Results from site 1097 of ODP Leg 178 show glacial influences as ice rafted till in S1, S2 and the upper part of S3 (e.g. Barker and Camerlenghi, 2002). The similarities of seismic reflection characteristics between S2 and Unit 2, and S1 and Unit 3, suggest glacial sediment transport during deposition of Unit 2 and Unit 3 and their correlating units $\mathrm{Be} 2$ and $\mathrm{Be} 1$ on the continental rise. Furthermore, Unit 2 and Unit 1 resemble the Type IA sequence, as defined by Cooper et al. (1991), which was interpreted to have been influenced by glacial erosion and transport processes. However, erosional truncations of prograding foresets are rarely seen within
Unit 2, which may indicate ice expansion without a strong erosional effect on the outer continental shelf. One possible origin of the strong acoustic impedance contrasts in $\mathrm{Be} 2$ is the presence of extensive slide/debris flow deposits interbedded with fine grained hemipelagic sediments. The question of whether or not the base of Be 2 represents the time of the first advance of grounded ice to the shelf edge remains open.

We think that the truncating unconformity beneath the outer shelf, between Unit 2 and Unit 3 (Fig. 6), most likely represents a strong erosional advance of grounded ice to the shelf edge, but we cannot define this as the first advance or advances of grounded ice to the shelf edge, because it could have removed evidence of previous ice advances. The onset of grounded ice events on the West-Antarctic continental shelf is still the subject of controversy and cannot be clarified in this study. However, we think that the change to strongly prograding units as shown by the Unit 2/Unit 3 boundary probably represents an important change in glacial dynamics that led to more strongly erosional ice advances. The boundary between units $\mathrm{Be} 2$ and $\mathrm{Be} 1$ coincides with a distinct buried acoustic reflector identified over a wide area on the Bellingshausen Sea continental rise by Tucholke and Houtz (1976) on Eltanin42 single channel data (track shown in Fig. 1), which demonstrates the regional extend of this boundary. Tucholke and Houtz named this reflector Horizon S. Comparison with data from other parts of the Antarctic continental slope and rise shows similar variations of seismic reflection characteristics from stratified units in the deeper part of a section to faulted reflections, channel levee complexes and other products of gravity driven processes in the upper part, as seen between $\mathrm{Be} 2$ and $\mathrm{Be} 1$. This change of seismic pattern is related to glacial erosion due to glaciation on the continental shelf (e.g. Hampton et al., 1987; Miller et al., 1990; Larter and Cunningham, 1993; Anderson, 1999).

The slightly decreasing progradation in the uppermost $0.3 \mathrm{~s}$ TWT of the outer shelf unit, Unit 3 (Fig. 6), is observed in the uppermost prograded sediments in many lines across the Antarctic Peninsula margin and elsewhere around Antarctica (e.g. Cooper et al., 1991; Bart and Anderson, 1995; Larter et al., 1997). Besides changes in climate and ice regime, a further influence on this change of progradation may be the fact that the most easily eroded sediment material is removed from the shelf by the first glaciations, leaving each subsequent glaciation with a deeper middle shelf and a more consolidated substrate. In this way, it is to be expected that erosion rates, and therefore sediment production rates, will decline with time given a sequence of glacial 
advances of similar magnitude. A statement on the frequency of ice advances over the continental margin of the Bellingshausen Sea is not possible with available data because the nearest age control comes from drilling at ODP Leg 178 on the western Antarctic Peninsula margin (Fig. 1).

\subsubsection{Age of sediment units}

Direct correlation of the continental rise units $\mathrm{Be} 1-$ Be3 with those of seismic profile I95-130 (of the Italian Programma Nazionale di Ricerche in Antartide, PNRA), recorded along the western Antarctic Peninsula, shows distinct differences in seismic stratigraphic pattern (Figs. 1 and 3 ) from which it is possible to infer differences in sediment supply and deposition on the Bellingshausen Sea and western Antarctic Peninsula margin. The units on the continental rise of the western Antarctic Peninsula were dated and classified by Rebesco et al. (1997, 2002) by correlation with ODP-sites from Leg 178 and one DSDP-site from Leg 35. The authors defined six stratigraphic units, numbered M1 to M6 from the seafloor down (Fig. 3). Units M6 (36-25 Ma) and M5 (25$15 \mathrm{Ma}$ ) were defined as a "Pre-drift Stage" and constitute turbiditic hemipelagic/pelagic, non-glacial sediments. Units M4 (15-9.6 Ma) and M3 (9.6-5.3 Ma), whose development was influenced by bottom currents, were ascribed to a "Drift growth Stage". The Units M2 (5.33.0) and M1 (3.0 Ma to the present) were interpreted as a "Drift maintenance Stage", showing mixed influence of bottom currents and glacial sediment transport. The westward continuation of sediment units M1-M6 on profile AWI-20010001 is not advisable due to the differences of the two sediment classification schemes. However, we can estimate the ages of units $\mathrm{Be} 1-\mathrm{Be} 3$ by correlating them with the units M1-M6. The correlation shows that the base of unit $\mathrm{Be} 2$ lies about $0.1 \mathrm{~s}$ TWT deeper than the base of Unit M3 (Fig. 3), interpreted as the base of mainly glacially derived sediment (Rebesco et al., 1997), and dated at 9.6 Ma using magnetostratigraphic data from ODP site 1095 (Iwai et al., 2002). Thus, discontinuous glacial sediment transport to the continental rise, which we infer to have produced $\mathrm{Be} 2$, started prior to $9.6 \mathrm{Ma}$. This conclusion is consistent with the result from ODP site 1095, where the base of glacially transported sediments was not reached and the oldest recovered material is dated at $9.6 \mathrm{Ma}$ (Barker and Camerlenghi, 2002). The boundary between Be1 and $\mathrm{Be} 2$ coincides with the base of Unit M2, dated at 5.3 Ma (Iwai et al., 2002). With respect to our interpretation of the corresponding Unit 2/Unit 3 boundary on the outer continental shelf, we infer that the unit $\mathrm{Be} 1 / \mathrm{Be} 2$ boundary indicates an increased sediment supply to the slope and rise due to grounded ice advances in the early Pliocene.

The change of seismic reflection characteristics west of approximately CDP 28000 of profile AWI-20010001 can be explained by changing down-slope sedimentation processes. The acoustic basement highs along the continental slope acted as a barrier to the downslope sediment supply, as seen on Profile AWI-94030 (Fig. 7) and led to discontinuous sedimentation between the continental shelf and rise. This results in different sediment accumulation patterns, compared to the eastern section of the Bellingshausen Sea continental rise. The unconformities in the upper western part of profile AWI-20010001 (dashed lines, Figs. 3 and 4c) may be caused by changing patterns of downslope sediment deposition, for example in response to changes in sediment input, slope instability or bottom currents. Due to the discontinuity of reflectors across CDP 28000, it is difficult to estimate the ages of sediment units identified on profile BAS-92324 (Fig. 5). Only the prominent unconformity, which may record the end of an uplift phase at the BGA at about $61 \mathrm{Ma}$ (e.g. Cunningham et al., 2002), constitutes a datable reflector. The sediments above the unconformity must therefore constitute the entire sediment deposition of the last 61 m.y. but a reason for the lower sedimentation rate is not obvious from available data.

\subsubsection{Sediment deposition rates}

Estimates of sediment deposition rates in the depocentres provide the opportunity to evaluate their respective glacial-derived sediment supplies and compare these to other sediment depocentres on the Antarctic continental rise. In order to roughly estimate the sediment deposition rates of units $\mathrm{Be} 1, \mathrm{Be} 2$ and $\mathrm{Be} 3$, we calculated sediment thicknesses at two locations on profile AWI-20010001 using the empirical travel-time versus depth relation of Carlson et al. (1986). We chose positions at CDPs 16500 and CDP 27400, at the crests of sediment Depocentres A and B because of their great sediment thicknesses (Fig. 3). The results are very high sedimentation rates for Be1, with values of $247 \mathrm{~m} / \mathrm{m}$.y. (CDP 16500) and $295 \mathrm{~m} / \mathrm{m}$.y. (CDP 27500), in contrast to sedimentation rates in $\mathrm{Be} 2(106 \mathrm{~m} / \mathrm{m} . \mathrm{y}$.) and $\mathrm{Be} 3$ (21 and $13 \mathrm{~m} / \mathrm{m} . \mathrm{y}$.) (Table 1). In comparison, the highest known sedimentation rate on the western Antarctic Peninsula rise is about $180 \mathrm{~m} / \mathrm{m}$.y. in the early Pliocene (mainly Unit M2), calculated on the basis of magnetobiochronologic data from ODP site 1096 (Iwai et al., 2002). The low sedimentation rates of $\mathrm{Be} 2$ and $\mathrm{Be} 3$ are less then those of their equivalent units (M3, M4, M5, M6) farther north-east on the western Antarctic 
Table 1

Variability in sedimentation of the Bellingshausen Sea

\begin{tabular}{|c|c|c|c|c|c|c|c|}
\hline $\mathrm{CDP}$ & Unit & TWT [s] & $\begin{array}{l}\text { Compacted } \\
\text { thickness [s] }\end{array}$ & $\begin{array}{l}\text { Sub-bott. } \\
\text { depth }[\mathrm{m}]\end{array}$ & $\begin{array}{l}\text { Compacted } \\
\text { thickness [m] }\end{array}$ & Age $[\mathrm{Ma}]$ & $\begin{array}{l}\text { Sediment deposition } \\
\text { rate }[\mathrm{m} / \mathrm{my}]\end{array}$ \\
\hline \multirow[t]{3}{*}{16500} & $\mathrm{Be} 1$ & 1.35 & 1.35 & 1310 & 1310 & 5.3 & 247 \\
\hline & $\mathrm{Be} 2$ & 1.70 & 0.35 & 1770 & 460 & 9.6 & 106 \\
\hline & $\mathrm{Be} 3$ & 2.20 & 0.50 & 2550 & 780 & 47 & 21 \\
\hline \multirow[t]{2}{*}{27400} & $\mathrm{Be} 1$ & 1.55 & 1.55 & 1560 & 1560 & 5.3 & 295 \\
\hline & $\mathrm{Be} 2$ and 3 & 2.00 & 0.45 & 2220 & 660 & 56 & 13 \\
\hline
\end{tabular}

Sediment depths, thicknesses and accumulation rates as estimated from the empirical travel-time versus depth relations for deep-sea sediments from Carlson et al. (1986). Depth (in $\mathrm{km}$ ) is calculated as $Z=-(3.03 \pm 0.24) \ln [1-(0.52 \pm 0.04) T]$ where $T$ is two-way travel-time in s.

Peninsula margin (Rebesco et al., 1997). The difference could be explained by a low rate of erosion prior to Pliocene times in the source area onshore. The BEDMAP compilation of subglacial topography (Lythe et al., 2000) shows that a large part of the subglacial rock surface in Ellsworth Land is below sea level. If the situation in the early Tertiary was similar, this area is unlikely to have been a significant source of eroded sediment material supplied to the continental margin. In contrast, the axis of the Antarctic Peninsula is a plateau, with peaks higher then $2000 \mathrm{~m}$, and thus a more likely site for ice sheet nucleation during the Miocene and a more plentiful source of eroded sediment material.

High sedimentation rates within unit Bel may be associated with development of very large ice drainage basins, high erosion rates on- and offshore, and high ice flow velocities during the Pliocene and Quaternary. Furthermore, the great width of the continental shelf (up to $480 \mathrm{~km}$ west of Alexander Island) may have led to increased glacial basal erosion and entrainment of sedimentary material due to the long transport distance. Sparse physiographic information about the Bellingshausen Sea continental shelf make estimates about transport paths during advances of grounded ice difficult. However, we assume that the western shelf trough indicated by swath bathymetry and sub-bottom profiler data in front of sediment Depocentre B (Fig. 9) acted as a major transport path for glacial sediment transport to the shelf edge. The cross-slope profile AWI-94030 shows that Depocentre B is not separated from the margin, but is in fact the lower part of a very uniform, low-angle, prograded slope (Fig. 7). These are typical characteristics of a trough mouth fan. Our estimation of a very high sediment deposition rate of unit $\mathrm{Be} 1$ and the structure and enormous width of Depocentre B support the interpretation of a trough mouth fan which seems to have been active in Pliocene and Quaternary times.

Although our calculations are crude approximations to sedimentation rates, the results nonetheless indicate a trend of increasing sediment accumulation rates since the early Pliocene. Conversely, ODP drilling on the continental margin of the western Antarctic Peninsula (Leg 178) indicate increasing deposition rates in the Late Miocene (base of unit M3) and a decrease in the Pliocene (base of unit M2, after Rebesco et al., 1997) (e.g. Iwai et al., 2002). This shows a remarkable difference in time of onset of high sediment deposition rates, which implies differences in the timing of the first erosional advance of grounded ice and, thus, variations of the glacial regime between the western Antarctic Peninsula and the Bellingshausen Sea continental margin. Further evaluations which could explain these differences in glacial development are not possible with existing data, but a complex history of multiple glacial advances and retreats in the Bellingshausen Sea can be inferred based on the presence of several thick prograding and aggrading sequence groups beneath the outer shelf as shown on Profile AWI-94030 (Fig. 7).

\subsubsection{Faults in Unit Be1}

Various processes may account for the structures in unit $\mathrm{Be} 1$ that resemble faults and listric shear planes, mainly observed between sediment Depocentres A and B (between CDPs 19000 and 28000) on profile AWI20010001 (Fig. 4b). We suppose that these features are the product of complex interactions between depositional processes and slope instability. The high sedimentation rate could have led to a high pore-water content, which was expelled during diagenesis. A further important diagenetic process may have been the transformation of opal-A to opal-CT, as observed at sites 1095 and 1096 of ODP-Leg 178 (Volpi et al., 2003). Local differential compression and compaction affected the sediment pile's stability. This process may have resulted in stress-discharge of sediments to the sides of the sediment depocentres and in the development of faults. The fault between CDPs 19000 and 21000 may have developed along the migrating locus 
of a facies boundary between the parallel layered sediments that accumulated on Depocentre A and a more chaotic regime on its steep western flank. At about CDP 24500, we can see the influence of basement structure on the stability of the upper sediments. Here, the crest of a basement high seems to act as a vertical wedge that amplifies the instability of the overlying sediments due to differential strain. Similar patterns have been observed in inter-drift areas along other Antarctic continental margins, such as along the western Antarctic Peninsula (e.g. Rebesco et al., 1997; Volpi et al., 2003) and in the Weddell Sea (e.g. Michels et al., 2002). Additional parallel seismic and bathymetric data are required to verify our suppositions concerning the occurrence of these faults.

\section{Conclusions}

This paper provides new constraints on the tectonic and large scale sedimentary architecture of the largely unexplored continental rise of the Bellingshausen Sea, mainly based on multi-channel seismic data. This study provides the following conclusions:

1) The basement structure on the continental rise permits the identification of tectonic fracture zones. At least two fracture zones (Alexander and Peter I FZs) and the ages of four spreading corridors can be estimated from seismic and magnetic data.

2) The sediment deposits in the middle part of the continental rise in the study area show distinct vertical variations in reflectivity characteristics. We divided the deposits into three sedimentary units, Be1-Be3, based on a correlation between the continental rise and the outer shelf via on cross-slope profile. On the continental rise, these three units can be correlated with stratigraphic Units M1-M6, identified on along-slope profiles on the western Antarctic Peninsula margin. Based on these correlations we infer:

The lowermost sedimentary unit, Be3, is older than 9.6 Ma. It probably consists of predominantly turbiditic sediments and the estimated sediment accumulation rate was low (up to $21 \mathrm{~m} / \mathrm{m} . \mathrm{y}$.).

The intermediate sedimentary unit, Be2, was developed between about 9.6 and 5.3 Ma and can be correlated with an intermediate prograding sedimentary unit on the shelf edge. We assume that unit $\mathrm{Be} 2$ mainly consists of sediments transported by ice advances on the continental shelf, but without strong erosion of the shelf surface. The sediment accumulation rate is estimated to be up to $106 \mathrm{~m} / \mathrm{m}$.y.

The age of the uppermost sedimentary unit, Be1, ranges from about 5.3 Ma up to present. We interpret this unit as consisting predominantly of terrigenous sediment transported across the shelf edge by strongly eroding grounded ice on the shelf, as shown by strong truncations of underlain foresets and strong progradation. An approximate sediment accumulation rate of around $295 \mathrm{~m} / \mathrm{m}$.y. is the highest known on the west Antarctic margin.

3) The high sediment deposition rate of unit $\mathrm{Be} 3$ implies an increase of sediment supply to the continental rise due to frequent advances of grounded ice on the continental shelf in the Pliocene and Quaternary, which is contrary to a decrease of the sediment deposition rate since Pliocene times on other sites of the Antarctic continental margin. The reason for this discrepancy remains unclear.

4) Two wide and previously unsurveyed sediment depocentres are identified on the continental margin of the Bellingshausen Sea. We name them Depocentre A in the east and Depocentre B in the west, and we show that they have developed in Pliocene and Quaternary times. Depocentre B is interpreted as a trough mouth fan and may constitute the main discharge area for glacially derived sediment material.

5) We interpret faults and listric shear planes inside unit Be1, mainly observed between the two sediment Depocentres $\mathrm{A}$ and $\mathrm{B}$, as the products of complex interactions between depositional processes and slope instability, reflecting the variability of sediment stability along the continental rise.

6) In the western Bellingshausen Sea, the characteristics of seismic reflections change entirely. Two alongslope orientated acoustic basement highs acted as barriers to sediment material supplied from the shelf, leading to a change in the conditions of sediment transport and deposition. The only clue to estimation of sediment ages west of $87^{\circ} \mathrm{W}$ is a prominent unconformity, identified on the elevated eastern side of a basement trough along the BGA. The unconformity is assumed to have developed at the end of tectonic uplift that occurred there around $61 \mathrm{Ma}$. The orientation of three westward thickening sedimentary minor units beneath the prominent unconformity may indicate a slightly westward dipping orientation of the basement before the uplift along the BGA.

Finally, we must emphasise that our interpretations in this paper about tectonic features and sediment deposits are mainly based on only one along-slope and one cross-slope seismic profile. To verify our conclusions and to improve knowledge about the tectonic and sedimentation history in the Bellingshausen Sea additional geophysical and geological investigations are required. 


\section{Acknowledgments}

We are grateful to the masters, officers and crews of $R V$ Polarstern and RRS James Clark Ross. This study is partly funded through grant no. GO $724 / 3-1$ of the Deutsche Forschungsgemeinschaft (DFG). Italian contribution is supported by SEDANO and MAGICO projects of the Italian Programma Nazionale di Ricerche in Antartide (PNRA).

\section{References}

Anderson, J.B., 1999. Antarctic Marine Geology. Cambridge Univ. Press. 289 pp.

Anderson, J.B., Wellner, J.S., Lowe, A.L., Mosola, A.B., Shipp, S.S., 2001. The footprint of the expanded West Antarctic ice sheet: ice stream history and behaviour. GSA Today 11, 4-9.

Barker, P.F., 1982. The Cenozoic subduction history of the Pacific margin of the Antarctic Peninsula: ridge crest interactions. J. Geol. Sci. 139, 787-801.

Barker, P.F., Camerlenghi, A., 2002. In: Barker, P.F., Camerlenghi, A., Acton, G.D., Ramsay, A.T.S. (Eds.), Glacial history of the Antarctic Peninsula from Pacific margin sedimentsProc. ODP, Sci. Results, vol. 178. [online]. Available from World Wide Web: <http:// wwwodp.tamu.edu/publications/178_SR/synth/synth.htm>.

Barker, P.F., Camerlenghi, A., Acton, G.D., et al., 1999. Proc. ODP, Init. Repts., 178 (CD-ROM). Available from: Ocean Drilling Program. Texas A\&M University, Collage Station, TX 77845-9547, USA.

Bart, P.J., Anderson, J.B., 1995. Seismic record of glacial events affecting the Pacific margin of the northwestern Antarctic Peninsula. In: Cooper, A.K., Barker, P.F., Brancolini, G. (Eds.), Geology and Seismic Stratigraphy of the Antarctic Margin. Antarctic Research Series, vol. 68. American Geophysical Union, Washington, DC, pp. 75-95.

Birkenmajer, K., 1991. Tertiary glaciation in the South Shetland Islands, West Antarctica: evaluation of data. In: Thomson, M. R.A., Crame, J.A., Thomson, J.W. (Eds.), Geological Evolution of Antarctica. Cambridge University Press, Cambridge, pp. 629-632.

Carlson, R.L., Gangi, A.F., Snow, K.R., 1986. Empirical reflection travel time versus depth and velocity versus depth functions for the deep sea sediment column. J. Geophys. Res. 91, 8249-8266.

Cooper, A.K., Barrett, P., Hinz, K., Traubea, V., Leitchenkov, G., Stagg, H., 1991. Cenozoic prograding sequences of the Antarctic continental margin: a record of glacioeustatic and tectonic events. Mar. Geol. 102, 175-213.

Cunningham, A.P., Larter, R.D., Barker, P.F., 1994. Glacially prograded sequences on the Bellingshausen Sea continental margin near $90^{\circ} \mathrm{W}$. Terra Antarctica 1, 267-268.

Cunningham, A.P., Larter, R.D., Barker, P.F., Gohl, K., Nitsche, F.-O., 2002. Tectonic evolution of the pacific margin of Antarctica: 2 . Structure of late Cretaceous-early Tertiary plate boundaries in the Bellingshausen Sea from seismic reflection and gravity data. J. Geophy. Res. 107 (B12), 2346. doi:10.1029/2002JB001897.

De Santis, L., Anderson, J.B., Brancolini, G., Zayatz, I., 1995. Seismic record of late Oligocene through Miocene glaciation on the central and eastern continental shelf of the Ross Sea. Antarct. Res. Ser. 68, $235-260$.
Dingle, R.V., Lavelle, M., 1998. Antarctic peninsular cryosphere: early Oligocene (c. $30 \mathrm{Ma}$ ) initiation and revised glacial chronology. J. Geol. Soc. 155 (3), 433-437.

Dowdeswell, J.A., Ó Cofaigh, C., Pudsey, C.J., 2004a. Thickness and extent of the subglacial till layer beneath an Antarctic paleo-ice stream. Geology 32, 13-16.

Dowdeswell, J.A., Ó Cofaigh, C., Pudsey, C.J., 2004b. Continental slope morphology and sedimentary processes at the mouth of an Antarctic palaeo-ice stream. Mar. Geol. 204, 203-214.

Eagles, G., Gohl, K., Larter, R.D., 2004a. Life of the Bellingshausen plate. Geophys. Res. Lett. 31, L07603.

Eagles, G., Gohl, K., Larter, R.D., 2004b. High resolution animated tectonic reconstruction of the South Pacific and West Antarctic margin. Geochem. Geophys. Geosyst. 5 (7), 1-21.

Gohl, K., Nitsche, F.O., Miller, H., 1997. Seismic and gravity data reveal Tertiary intraplate subduction in the Bellingshausen Sea, southeast Pacific. Geology 25, 371-374.

Hampton, M.A., Eittreim, S.L., Richmond, B.M., 1987. Post-breakup sedimentation on the Wilkes Land Margin, Antarctica. In: Eittreim, S.L., Hampton, M.A. (Eds.), The Antarctic Continental Margin, Geology and Geophysics of Offshore Wilkes LandCircum-Pacific Council for Energy and Mineral Recourses, Earth Science Series, vol. 5 A, pp. $75-89$.

Hollister, C.D., Craddock, C., et al., 1976. Initial Reports of Deep Sea Drilling Project, vol. 35. U.S. Government Printing Office, Washington D.C. 929 pp.

Iwai, M., Acton, G.D., Lazarus, D., Osterman, L.E., Williams, T., 2002. Magnetobiochronologic synthesis of ODP Leg 178 rise sediments from the Pacific sector of the Southern Ocean: Sites 1095, 1096 and 1101. In: Barker, P.F., Camerlenghi, A., Acton, G.D., Ramsay, A.T.S., (Eds.), Proc. ODP, Sci. Results, vol. 178, pp. 1-40. CD-Rom.

Kimura, K., 1982. Geological and geophysical survey in the Bellingshausen Basin, off Antarctica. Antarct. Rec. 75, 12-24.

Larter, R.D., Barker, P.F., 1991. Effects of ridge crest-trench interaction on Antarctic-Phoenix spreading: forces on a young subducting plate. J. Geophys. Res. 96, 19583-19608. doi:10.1029/ 2000JB000052 (2345).

Larter, R.D., Cunningham, A.P., 1993. The depositional pattern and distribution of glacial-interglacial sequences on the Antarctic Peninsula Pacific margin. Mar. Geol. 109, 203-219.

Larter, R.D., Rebesco, M., Vanneste, L.E., Gambôa, L.A.P., Barker, P. F., 1997. Cenozoic tectonic, sedimentary and glacial history of the continental shelf west of Graham Land, Antarctic Peninsula. In: Cooper, A.K., Barker, P.F. (Eds.), Geology and Seismic Stratigraphy on the Antarctic Margin: Part 2. American Geophysical Union, Antarctic Research Series, vol. 71. American Geophysical Union, Washington, DC, pp. 1-27.

Larter, R.D., Cunningham, A.P., Barker, P.F., Gohl, K., Nitsche, F.-O., 1999. Structure and tectonic evolution of the West Antarctic continental margin and Bellingshausen Sea. Korean J. Polar Res. 10, 125-133.

Larter, R.D., Cunningham, A.P., Barker, P.F., Gohl, K., Nitsche, F.-O., 2002. Tectonic evolution of the pacific margin of Antarctica: 1. Late Cretaceous tectonic reconstructions. J. Geophys. Res. 107 (B12).

Larter, R.D., Dowdeswell, J.A., Pudsey, C.J., Evans, J., Hillenbrand, C.-D., Morris, P., Ó Cofaigh, C., 2004. Investigations of a major palaeo-outlet of the West Antarctic ice sheet in the southern Bellingshausen Sea: preliminary results from RRS James Clark Ross Cruise JR104, Terra Nostra, Schriften der Alfred-Wegener_ Stiftung 2004/4, SCAR Open Science Conference Abstract 
Volume, 252. http://www.scar28.org/SCAR/SCARmeeting/ Wednesday/PDF/S_11_oral.pdf.

Lythe, M.B., Vaughan, D. G., BEDMAP Consortium, 2000. BEDMAP - Bed topography of the Antarctic, scale 1:10,000,000. Brit. Antarct. Surv., Cambridge, U.K. Available from World Wide Web: $<$ http://www.antarctica.ac.uk/aedc/bedmap/database/>.

McAdoo, D.C., Laxon, S., 1997. Antarctic tectonics: constraints from an ERS-1 satellite marine gravity field. Science 276, 556-560.

McCarron, J.J., Larter, R.D., 1998. Late Cretaceous to early Tertiary subduction history of the Antarctic Peninsula. J. Geol. Soc. (Lond.) 155, 255-268.

McGinnes, J.P., Hayes, D.E., Driscoll, N.W., 1997. Sedimentary processes across the continental rise of the southern Antarctic Peninsula. Mar. Geol. 141, 91-109.

Miller, K.G., Fairbanks, R.G., Mountain, G.S., 1987. Tertiary oxygen isotope synthesis, sea-level history and continental margin erosion. Paleoceanography 2, 1-19.

Miller, H., Henriet, J.P., Kaul, N., Moons, A., 1990. A fine scale seismic stratigraphy of the eastern margin of the Weddell Sea. In: Bleil, U., Thiede, J. (Eds.), Geological History of the Polar Oceans: Arctic versus Antarctic. Kluwer Academ. Publ., Boston, pp. 131-161.

Michels, K.H., Kuhn, G., Hillenbrand, C.-D., Diekmann, B., Fütterer, D.K., Grobe, H., Uenzelmann-Neben, G., 2002. The southern Weddell Sea: combined contourite-turbidite sedimentation at the southeastern margin of the Weddell Gyre. In: Stow, D.A.V., Pudsey, C.J., Howe, J., Faugeres, J.-C., Viana, A. (Eds.), DeepWater Contourite Systems: Modern Drifts and Ancient Series, Seismic and Sedimentary CharacteristicsSpec. Publ. Geol. Soc. London. Memoirs, vol. 22, pp. 305-323.

Nitsche, F.O., Gohl, K., Vanneste, K., Miller, H., 1997. Seismic expression of glacially deposited sequences in the Bellingshausen and Amundsen Seas, West Antarctica. In: Barker, P.F., Cooper, A. K. (Eds.), Geology and Seismic Stratigraphy of the Antarctic Margin: 2. Antarctic Research Series, vol. 71. American Geophysical Union, Washington, DC, pp. 95-108.

Nitsche, F.O., Cunningham, A.P., Larter, R.D., Gohl, K., 2000. Geometry and development of glacial continental margin depositional systems in the Bellingshausen Sea. Mar. Geol. 162, 277-302.

Ó Cofaigh, C., Larter, R.D., Dowdeswell, J.A., Hillenbrand, C-D., Pudsey, C.J., Evans, J., Morris, P., 2005. Flow of the West Antarctic ice sheet on the continental margin of the Bellingshausen
Sea at the Last Glacial Maximum. J. Geophys. Res., 110, doi: 10.1029. 2005JB003619.

Rebesco, M., Larter, R.D., Camerlenghi, A., Barker, P.F., 1996. Giant sediment drifts on the continental rise west of the Antarctic Peninsula. Geo Mar. Lett. 16, 65-75.

Rebesco, M., Larter, R.D., Barker, P.F., Camerlenghi, A., Vanneste, L. E., 1997. History of sedimentation on the continental rise west of the Antarctic Peninsula. In: Cooper, A.K., Barker, P.F. (Eds.), Geology and Seismic Stratigraphy on the Antarctic Margin: 2. Antarctic Research Series, vol. 71. American Geophysical Union, Washington, DC, pp. 29-49.

Rebesco, M., Pudsey, C.J., Canals, M., Camerlenghi, A., Barker, P.F., Estrada, F., Giorgetti, A., 2002. Case study 27: sediment drifts and deep-sea channel systems, Antarctic Peninsula Pacific margin, mid-Miocene to present. In: Stow, D.A.V., Pudsey, C.J., Howe, J., Faugeres, J.-C., Viana, A. (Eds.), Deep-Water Contourite Systems: Modern Drifts and Ancient Series, Seismic and Sedimentary Characteristics. Spec. Publ. Geol. Soc. London. Memoirs, vol. 22, pp. 353-371.

Smith, W.H.F., Sandwell, D.T., 1997. Global seafloor topography from satellite altimetry and ship depth soundings. Science 277 , 1956-1961.

Tomlinson, J.S., Pudsey, C.J., Livermore, R.A., Larter, R.D., Barker, P. F., 1992. Long-range sidescan sonar (GLORIA) survey of the Antarctic Peninsula pacific margin. In: Yoshida, Y., Kaminuma, K., Shiraishi, K. (Eds.), Recent Progress in Antarctic Earth Science. Terra Scientific Publishing Company, Tokyo, pp. 423-429.

Troedson, A.L., Smellie, J.L., 2002. The Polonez Cove Formation of King George Island, West Antarctica: stratigraphy, facies and palaeoenvironmental implications. Sedimentology 49, 277-301.

Tucholke, B.E., Houtz, R.E., 1976. Sedimentary framework of the Bellingshausen Basin from seismic profile data. In: Hollister, C.D., Craddock, C.D., et al. (Eds.), Initial Reports of the Deep Sea Drilling Project, vol. 35. U.S. Government Printing Office, Washington, DC, pp. 197-227.

Volpi, V., Camerlenghi, A., Hillenbrand, C.-D., Rebesco, M., Ivaldi, R., 2003. Effects of biogenic silica on sediment compaction and slope stability on the Pacific margin of the Antarctic Peninsula. Basin Res. 15, 339-363.

Zachos, J., Pagani, M., Sloan, L., Thomas, E., Billups, K., 2001. Trends, rhythms, and aberrations in global climate $65 \mathrm{Ma}$ to present. Science 292, 686-693. 